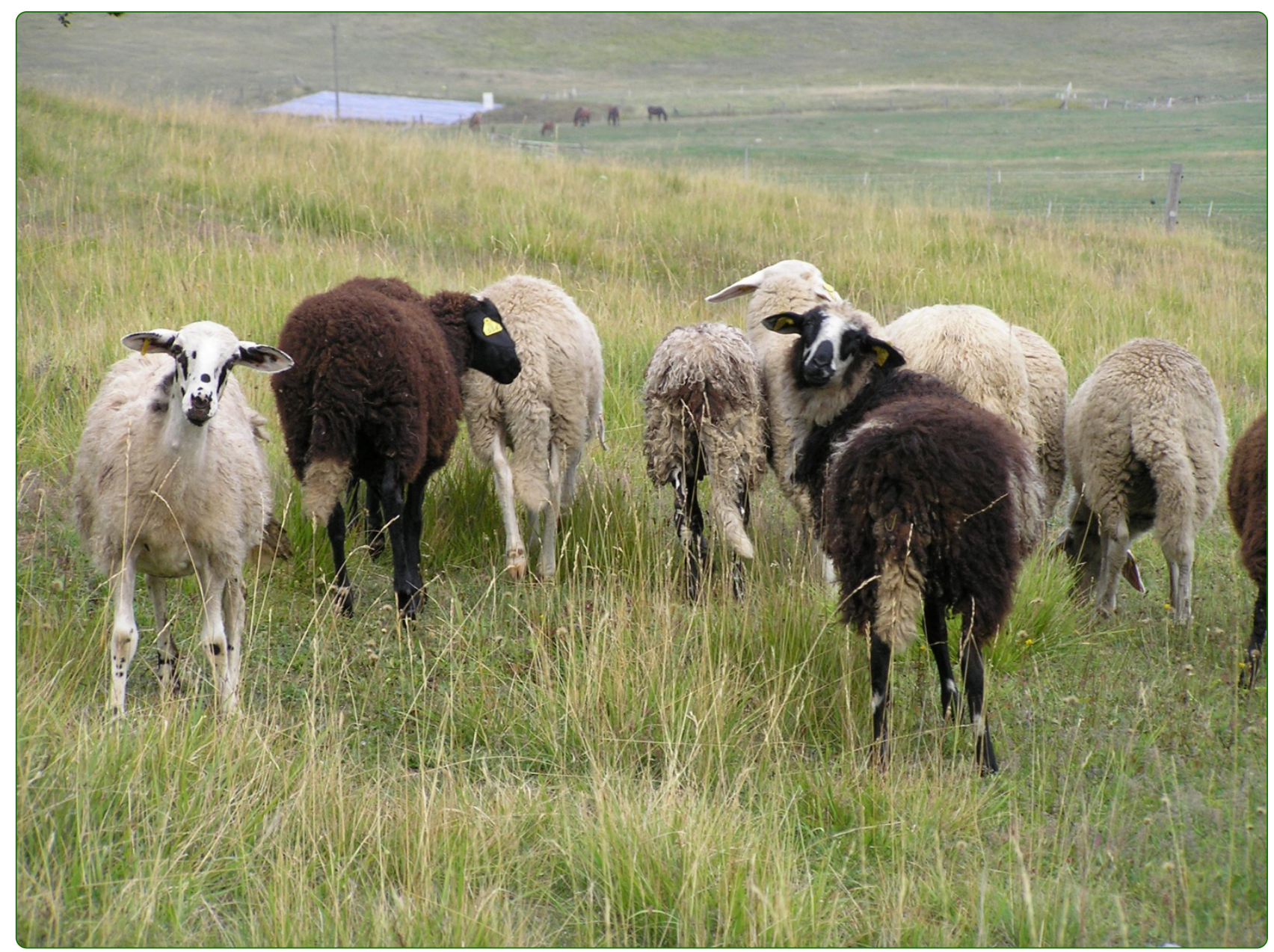

\title{
Fluctuations of serum cortisol, insulin and non-esterified fatty acid concentrations in growing ewes over the year
}

Snoj et al. 


\title{
Fluctuations of serum cortisol, insulin and non-esterified fatty acid concentrations in growing ewes over the year
}

Tomaz Snoj ${ }^{1}$, Zlatko Jenko ${ }^{2}$ and Nina Cebulj-Kadunc ${ }^{{ }^{*}}$

\begin{abstract}
Background: The physiological levels of endocrine and metabolic parameters in Slovene autochthonous breeds of sheep are not yet well known, nor are the mechanisms of their adaptability and responses to climate and environmental factors.

Therefore, the aim of this study was to evaluate fluctuations of cortisol, insulin and non-esterified fatty acids (NEFA) in growing ewes over an one-year period. Blood samples were collected monthly from 10 yearling Jezersko-Solchava, 10 Bovec and 10 Istrian ewes. Serum cortisol, insulin and NEFA were measured with commercial kits.

Results: Mean monthly cortisol values fluctuated with low levels in summer and high levels in autumn. Significant peaked cortisol values of $25.69 \pm 6.89,14.67 \pm 2.43$ and $21.11 \pm 7.25 \mu \mathrm{g} / \mathrm{L}$ in Jezersko-Solchava, Bovec and Istrian breed, respectively, were found in September (Bovec breed) and October (Jezersko-Solchava and Istrian breed). Mean monthly insulin values increased during the observation period. The highest levels of $14.60 \pm 3.15,16.03 \pm 5.35$ and $12.56 \pm 2.52$ $\mu \mathrm{IU} / \mathrm{mL}$ in Jezersko-Solchava, Bovec and Istrian breed, respectively, were observed in the last sample collection in May. NEFA concentrations were found to be low except in some autumn and spring months. The peak values were observed in March for Jezersko-Solchava and Istrian breed ( $0.60 \pm 0.05$ and $0.66 \pm 0.10 \mathrm{mmol} / \mathrm{L})$, and in April for Bovec breed $(0.71 \pm 0.11 \mathrm{mmol} / \mathrm{L})$.

Conclusions: Monthly fluctuations of cortisol, insulin and NEFA were measured in all observed sheep breeds, but between-breed differences in monthly values of examined parameters were insignificant. Significantly increased serum cortisol levels were found in autumn for all breeds and were probably associated with the onset of puberty and low environmental temperature. A gradual increase of insulin level in the examined ewes was in parallel with their growth. Significantly higher NEFA values in spring suggest qualitatively insufficient feed supply during that period.
\end{abstract}

Keywords: Jezersko-Solchava breed, Bovec breed, Istrian breed, Growing ewes, Energy metabolism, Cortisol, Insulin, NEFA

\section{Background}

Autochthonous Slovene breeds of sheep (Jezersko-Solchava, Bovec and Istrian breed) have been bred in the territory of the Republic of Slovenia for several centuries and used for wool as well as meat (Jezersko-Solchava breed) or milk (Bovec and Istrian breed) production. The physiological levels of endocrine and metabolic parameters in these sheep breeds are not yet well known, nor are the mechanisms of their adaptability and responses to climate and

\footnotetext{
* Correspondence: nina.cebulj.kadunc@vf.uni-lj.si

'Institute of Physiology, Pharmacology and Toxicology, University of

Ljubljana, Veterinary faculty, Gerbiceva 60, Ljubljana, Slovenia

Full list of author information is available at the end of the article
}

environmental factors. In addition to new findings of the physiological characteristics in the autochthonous sheep breeds, their conservation and reintroduction, the knowledge of their properties contributes to the identification of their nutritional status, prevention of metabolic disturbances and economic viability of livestock operations. Such studies also offer reference data for further research of food restriction, long term feeding rhythms and accompanying changes of energy metabolism and metabolical hormones in sheep as models in research of obesity or diabetes in humans. The present study focuses on circulating profiles of cortisol and insulin, which are hormones known to influence energy metabolism, and non-esterified 
fatty acids (NEFA) levels as a reflection of energy balance in ruminants, in an one-year period.

Cortisol, the most important glucocorticoid in sheep, exerts profound effects on the intermediary metabolism of carbohydrates, proteins and fats, accelerating gluconeogenesis and lipolysis with the release of glycerol and free fatty acids (an insulin antagonistic effect), and inhibiting protein synthesis [1,2]. Cortisol synthesis is regulated through the hypothalamo-pituitary-suprarenal axis [1], but circadian and seasonal fluctuations of this hormone have been described in sheep as having the highest values, particularly in non-pregnant females, during winter or spring [3-6]. Synthesis and secretion of cortisol is accelerated by various forms of stress, like relocation of sheep to a foreign environment or isolation from the flock as well as several physical (ambient temperature), metabolic, immunological and psychological stressors like the time of feeding and handling of animals [7-11].

In contrast to cortisol, insulin promotes fuel storage in the liver by the stimulation of glycogen synthesis and storage as well as the formation of precursors of fatty acid synthesis [2]. The insulin level is strongly affected by feed supply or fasting [1], and is found to be in inverse relationship with NEFA [12]. Additionally, an increase of insulin level was found during animal growth [13]. In sheep, some differences in insulin secretion were described in relation to photoperiod [14].

NEFA as a product of hydrolysis of triglycerides, stored in adipose tissue, can be used as an energy source by several tissues. In ruminants, NEFA levels reflect triglyceride metabolism, since the levels increase during starvation or poor feed supply due to energy demand induced lipolysis [15-17].

In the light of the regulation of energy metabolism and adaptability to environmental conditions, the goal of our study was to follow monthly fluctuations of cortisol, insulin and NEFA in growing ewes of three autochthonous Slovene breeds of sheep over an one year period. Peak cortisol values were expected during the winter period, characterized by extremely low environmental temperatures. With regard to the literature data, seasonal fluctuations were also assumed in insulin and NEFA concentrations. Due to various biological characteristics, use and origin of examined breeds, differences between the breeds for measured values and/or their timeline were also expected.

\section{Methods}

\section{Animals}

The study was performed in a flock of 30 yearling ewes of autochthonous Slovene breeds (10 Jezersko-Solchava, 10 Bovec and 10 Istrian ewes), aged approximately 3 months at the onset of the study ( $92 \pm 8$ days in Jezersko-Solchava, $99 \pm 16$ days in Bovec and $107 \pm 11$ days in Istrian breed). The ewes were kept on a free pasture of dry Mediterranean karst grasslands utilising a rotational grazing system from the beginning of May to mid-October, separately from the parent flock. During the rest of the year, they were kept free in a stable. They had no contact with rams and were not pregnant at the time of observation. While stabled, they were fed twice a day with hay originating from the farm and containing $5.6 \%$ crude protein, $34.2 \%$ crude fibre and $1.5 \%$ crude fat. Additional rations of a feed mixture for ecological farming (Alpenkorn Lämmer; Unser Lagerhaus, Klagenfurt, Austria) were offered in an average daily amount of $150 \mathrm{~g}$ per animal while vitamin-mineral supplementary feed and water were available ad libitum.

With regard to the clinical examinations and herd history, the studied sheep were deemed clinically healthy throughout the study and dewormed regularly with albendazol (Monil ${ }^{\circ} 5 \%$ suspension, treated orally $0.1 \mathrm{~mL} / \mathrm{kg}$; produced by Genera, Kalinovica, Croatia).

Animals were kept on the Karst territory, a subMediterranean region at the latitude $45^{\circ} 41^{\prime} \mathrm{N}, 14^{\circ} 01^{\prime} \mathrm{E}$ and at $760 \mathrm{~m}$ above the sea level. Average monthly temperatures during the observational period ranged from $3.7^{\circ} \mathrm{C}$ in December and January to $22.4^{\circ} \mathrm{C}$ in July. Daily temperatures below $0^{\circ} \mathrm{C}$ were observed in the period from October to March. Average monthly rainfall ranged from $56.5 \mathrm{~mm}$ in January to $201,5 \mathrm{~mm}$ in October [18].

\section{Sampling}

The study protocol and sampling procedure were approved by the Veterinary Administration of the Republic of Slovenia (license number 323-02-201/2003-3).

Blood samples were collected twice monthly with a 10-day interval (on the first Tuesday and the second Thursday of the month) starting in June and finishing in May the following year, at the same time of day: between 8.00 and $9.30 \mathrm{am}$. Blood was sampled with a jugular vein puncture, using plain $5 \mathrm{~mL}$ vacuum tubes (Vacutainer, Becton Dickinson, Heidelberg, Germany). After the samples arrived at the laboratory (4 to 5 hours after sampling), the tubes were immediately centrifuged and the blood serum was stored in aliquots of $300 \mu \mathrm{L}$ on $-80^{\circ} \mathrm{C}$ until analysed.

Along with blood sampling, all of the animals were also weighed (balance Tru-Test ser. 700, Auckland, New Zealand). The ewes were familiar with humans and used to various handling procedures.

\section{Measurements of cortisol, insulin, NEFA and progesterone concentrations}

Cortisol and insulin concentrations were both determined in the first monthly samples with commercial EIA kits (Diagnostic Systems Laboratories, Webster, USA) following the instructions for users. As reported in the instructions for use, the sensitivity of the cortisol EIA kit is $0.1 \mu \mathrm{g} / \mathrm{L}$; in the serial dilution studies, the results were 
linear to the concentrations of $1.6 \mu \mathrm{g} / \mathrm{L}$ to $1.7 \mu \mathrm{g} / \mathrm{L}$ with $81 \%$ to $118 \%$ recoveries. The precision of the kit was estimated with intra- and inter-assay coefficients of variation (CV), which were $8.77 \%$ and $9.91 \%$ for low $(3.88 \pm$ $0.34 \mu \mathrm{g} / \mathrm{L}$ ) and $4.15 \%$ and $8.49 \%$ for high cortisol values $(19.56 \pm 0.81 \mu \mathrm{g} / \mathrm{L})$ in ovine serum. The sensitivity of the insulin EIA kit, reported in the instructions for use, is 0.26 $\mu \mathrm{IU} / \mathrm{mL}$, and in the serial dilution studies, results were linear to the concentrations of 3.2 to $5.6 \mu \mathrm{IU} / \mathrm{mL}$ with $82 \%$ to $119 \%$ recoveries. The precision of the kit, estimated with intra- and inter-assay CVs, was $8.07 \%$ and $5.49 \%$ for low $(11.31 \pm 0.96 \mu \mathrm{IU} / \mathrm{mL})$ and $9.60 \%$ and $9.17 \%$ for high insulin values $(28.69 \pm 2.75 \mu \mathrm{IU} / \mathrm{mL})$ in ovine serum.

NEFA were measured in the first monthly samples with an enzyme-colorimetric method using a commercial kit (Wako Chemicals, Neuss, Germany) following the instructions for users. The precision of the NEFA assay, as estimated by CVs, was $4.55 \%$ for low $(0.044 \pm 0.002 \mathrm{mmol} / \mathrm{L})$, and $0.86 \%$ for high $(2.81 \pm 0.018 \mathrm{mmol} / \mathrm{L})$ bovine concentrations. The accuracy of the method, established with the analyses of regression, displayed the regression line between the measured and added quantity of NEFA of $y=0.96 x+0.022$. The detailed validation of NEFA measurement is described elsewhere [19]. Absorbance was measured with a Cobas Mira biochemical analyser (Hoffman-La Roche, Basel, Switzerland).

Serum progesterone concentrations were measured twice monthly by a commercial EIA kit (Ovucheck ${ }^{\circ}$ Plasma or Serum Progesterone, Biovet Canada, Saint Hyacinthe, Quebec, Canada). The range of the test was from 1.59 to $95.39 \mathrm{nmol} / \mathrm{L}$ of serum. Coefficients of variation were $7.9 \%$ for low values $(4.88 \pm 0.33 \mathrm{nmol} / \mathrm{L})$ and $9.65 \%$ for high values $(86.38 \pm 2,25 \mathrm{nmol} / \mathrm{L})$.

Ovarian activity was evaluated on the basis of progesterone concentrations measured in the both monthly samples. The interval between samplings was selected considering a mean cycle duration of 14-21 days and mean progesterone fluctuations during the oestrous cycle of the ewe. Progesterone concentrations higher than $6.4 \mathrm{nmol} / \mathrm{L}$ were considered as indicators for the luteal phase and concentrations below $3.4 \mathrm{nmol} / \mathrm{L}$ for follicular phase or anoestrus [20-23]. Two consecutive high progesterone concentrations or one high and one low concentration in the same month were considered as indicators of oestrous cycle and two consecutive low concentrations in the same month as an indicator of anoestrus, as reported previously [22].

\section{Statistical evaluation}

Data was analysed using SPSS 20.0 IBM commercial software (Chicago, USA) General Linear Model with Multivariate Analysis was used for testing of breed $\times$ time interaction and one way repeated measures analysis of variance (RM ANOVA) for comparison of values by month for each breed and between breeds for each month.
Normality was assessed with a Shapiro-Wilk test and significance with all pairwise multiple comparison procedures (Tukey test). Pearson product moment correlation was used for examining correlations between the results. The results were evaluated as statistically significant at $\mathrm{P}<0.05$ and are presented here as the mean \pm standard error of the mean (mean \pm s.e.m.).

\section{Results \\ Body weight}

The mean body weights of the Jezersko-Solchava, Bovec and Istrian ewes at each weighing time are presented in Table 1 . Mean body weight increased with every consecutive weighing except in Jezersko-Solchava ewes where an insignificant loss of mean body weight was observed between April and May.

\section{Reproductive activity}

The number and proportion of ewes within each breed exhibiting signs of ovarian activity are presented in Table 2.

Ovarian activity in all three examined breeds started in September and lasted till March in Jezersko-Solchava breed, till May in Bovec breed and till December in Istrian breed. Ovarian activity in Jezersko-Solchava ewes lasted 2 to 6.5 months (average $3.86 \pm 0.58$ months) and in Bovec ewes from 1,5 to 7,5 months (averagely $3.95 \pm 0.56$ months). In Istrian breed, only two ewes shoved signs of ovarian activity, which lasted 30 or 90 days.

\section{Serum cortisol}

Monthly variations in cortisol profiles were recorded in all examined sheep breeds (Figure 1) with the lowest serum cortisol concentrations measured in June for Istrian breed $(3.37 \pm 0.57 \mu \mathrm{g} / \mathrm{L})$ and in July for Jezersko-Solchava and Bovec breeds $(5.19 \pm 0.65 \mu \mathrm{g} / \mathrm{L}$ and $5.76 \pm 0.90 \mu \mathrm{g} / \mathrm{L}$ respectively). Thereafter, the cortisol concentration in all breeds increased gradually to reach a significant peak $(\mathrm{P}<0.001)$ in September in Bovec $(14.67 \pm 2.43 \mu \mathrm{g} / \mathrm{L})$, and in October in Jezersko-Solchava and Istrian breeds (25.69 \pm $6.89 \mu \mathrm{g} / \mathrm{L}$ and $21.11 \pm 7.25 \mu \mathrm{g} / \mathrm{L}$ ). In the following months of the study, the cortisol concentrations decreased again. The RM ANOVA demonstrated significant differences between the monthly cortisol concentration for each breed ( $\mathrm{P}<0.001)$, but there was no significant interaction $(P=0.239)$ between each breed and month of sampling. Differences in cortisol concentration between breeds were insignificant for every month of the study with the exception of November between Jezersko-Solchava and Istrian breed $(\mathrm{P}<0.05)$.

\section{Serum insulin}

Monthly variations of insulin concentrations were recorded in all sheep breeds included in the study (Figure 2). The lowest serum insulin concentrations were measured 
Table 1 Mean body weight (BW) of Jezersko-Solchava (JS), Bovec (BO) and Istrian (IP) sheep at sampling time

\begin{tabular}{|c|c|c|c|c|c|c|c|c|c|c|c|c|c|}
\hline \multirow[t]{2}{*}{ Breed } & \multirow[t]{2}{*}{ BW (kg) } & \multicolumn{12}{|c|}{ Time of weighting (months of the year) } \\
\hline & & Jun & Jul & Aug & Sep & Oct & Nov & Dec & Jan & Feb & Mar & Apr & May \\
\hline \multirow[t]{2}{*}{ JS } & mean & 24.8 & 28.7 & 29.6 & 31.5 & 33.1 & 34.9 & 37.2 & 37.7 & 38.5 & 40.4 & 40.5 & 39.9 \\
\hline & s.e.m. & 2.71 & 3.30 & 2.47 & 2.49 & 2.20 & 2.35 & 3.56 & 3.18 & 2.82 & 3.07 & 2.89 & 2.13 \\
\hline \multirow[t]{2}{*}{$\mathrm{BO}$} & mean & 21.0 & 25.5 & 25.9 & 27.7 & 28.8 & 30.1 & 32.5 & 32.9 & 34.3 & 36.4 & 36.9 & 37.2 \\
\hline & s.e.m. & 3.29 & 3.69 & 2.27 & 3.10 & 3.50 & 3.13 & 3.66 & 3.97 & 3.68 & 4.84 & 4.67 & 5.06 \\
\hline \multirow[t]{2}{*}{ IP } & mean & 23.3 & 25.2 & 25.3 & 27.7 & 29.2 & 30.3 & 31.7 & 32.0 & 32.4 & 33.5 & 34.4 & 34.7 \\
\hline & s.e.m. & 3.06 & 3.52 & 2.63 & 3.39 & 3.42 & 3.86 & 3.27 & 3.35 & 3.42 & 4.28 & 3.73 & 4.42 \\
\hline
\end{tabular}

in June for Jezersko-Solchava and Bovec breeds (4.53 \pm $0.35 \mu \mathrm{IU} / \mathrm{mL}$ and $6.25 \pm 1.54 \mu \mathrm{IU} / \mathrm{mL}$, respectively) and in August for Istrian breed $(6.49 \pm 0.66 \mu \mathrm{IU} / \mathrm{mL})$ and the highest in May for Jezersko-Solchava (14.60 \pm 3.15 $\mu \mathrm{IU} / \mathrm{mL})$, Bovec $(16.03 \pm 5.35 \mu \mathrm{IU} / \mathrm{mL})$ and Istrian breed $(12.56 \pm 2.52 \mu \mathrm{IU} / \mathrm{mL})$. The RM ANOVA demonstrated significant differences between the monthly insulin concentration for each breed of ewes $(\mathrm{P}<0.01)$, but there was no significant interaction $(P=0.751)$ between each breed and month of sampling. Differences in insulin concentration between breeds were insignificant for every month of study with the exception of August between Bovec and Istrian breeds $(\mathrm{P}<0.05)$.

\section{Serum NEFA}

Significant monthly variations in NEFA profiles (Figure 3) were recorded for each of examined sheep breeds, confirmed by the RM ANOVA ( $\mathrm{P}<0.05)$. The lowest serum NEFA concentrations were measured in September $(0.14 \pm 0.01 \mu \mathrm{IU} / \mathrm{mL}$ for Jezersko-Solchava, $0.19 \pm 0.03$ $\mu \mathrm{IU} / \mathrm{mL}$ for Bovec and $0.16 \pm 0.04 \mu \mathrm{IU} / \mathrm{mL}$ in Istrian breed) while the highest values for Jezersko-Solchava and Istrian breeds were measured in March $(0.60 \pm$ $0.05 \mathrm{mmol} / \mathrm{L}$ and $0.66 \pm 0.10 \mathrm{mmol} / \mathrm{L}$, respectively) and for Bovec breed in April $(0.71 \pm 0.11 \mathrm{mmol} / \mathrm{L})$. There was no significant interaction $(P=0.144)$ between each breed and month of sampling. Differences in NEFA concentration between breeds were insignificant for every month of study with the exception of October between Jezersko-Solchava and Istrian breed $(\mathrm{P}<0.05)$ and in
April for Bovec versus Jezersko-Solchava and Istrian breed $(\mathrm{P}<0.05)$.

\section{Correlations}

Correlation coefficients $\left(\mathrm{r}^{2}\right)$ between body weight, serum cortisol, insulin and NEFA concentrations in JezerskoSolchava, Bovec and Istrian ewes are represented in Table 3.

\section{Discussion}

All measured parameters had shown fluctuations over the observation period (Figures 1, 2 and 3). In contrast to our expectations, there were no significant differences between the breeds when comparing monthly values of the measured parameters.

Cortisol levels measured at all sampling times and in all examined breeds were in the range determined in some other sheep breeds, like in Rommey Marsh ewes $(5-20 \mu \mathrm{g} / \mathrm{L})$ [24], Dorset-sired crossbred ewes (10 $20 \mu \mathrm{g} / \mathrm{L}$ ) [11] and mature Merino ewes (below $20 \mu \mathrm{g} / \mathrm{L}$ ) [25], but lower than in Comisana ewes $(30-40 \mu \mathrm{g} / \mathrm{L})$ [9] or Suffolk $\times$ Hampshire ewes $(28-38 \mu \mathrm{g} / \mathrm{L})$ [10], all of them being tethered or housed in pens.

Cortisol has shown a similar pattern of fluctuations in all examined breeds (Figure 1) and insignificant betweenbreed differences, with the lowest values observed during summer, intermediate in spring and winter and the highest values being observed in autumn. We believe that stress situations like relocation of sheep to a foreign environment or isolation from the flock, immunological or psychological

Table 2 The number and proportion of Jezersko-Solchava (JS), Bovec (BO) and Istrian (IP) ewes exhibiting signs of oestrus

\begin{tabular}{|c|c|c|c|c|c|c|c|c|c|c|c|c|c|}
\hline \multirow[t]{2}{*}{ Breed } & \multirow[t]{2}{*}{ Value } & \multicolumn{12}{|c|}{ Time of the year [months of the year] } \\
\hline & & Jun & Jul & Aug & Sep & Oct & Nov & Dec & Jan & Feb & Mar & Apr & May \\
\hline \multirow[t]{2}{*}{ JS } & Number [n] & 0 & 0 & 0 & 1 & 4 & 8 & 8 & 7 & 4 & 1 & 0 & 0 \\
\hline & Proportion [\%] & 0 & 0 & 0 & 10 & 40 & 80 & 80 & 70 & 40 & 10 & 0 & 0 \\
\hline \multirow[t]{2}{*}{$\mathrm{BO}$} & Number [n] & 0 & 0 & 0 & 3 & 4 & 8 & 10 & 9 & 7 & 3 & 2 & 1 \\
\hline & Proportion [\%] & 0 & 0 & 0 & 30 & 40 & 80 & 100 & 90 & 70 & 30 & 20 & 10 \\
\hline \multirow[t]{2}{*}{ IP } & Number [n] & 0 & 0 & 0 & 2 & 1 & 1 & 1 & 0 & 0 & 0 & 0 & 0 \\
\hline & Proportion [\%] & 0 & 0 & 0 & 20 & 10 & 10 & 10 & 0 & 0 & 0 & 0 & 0 \\
\hline
\end{tabular}




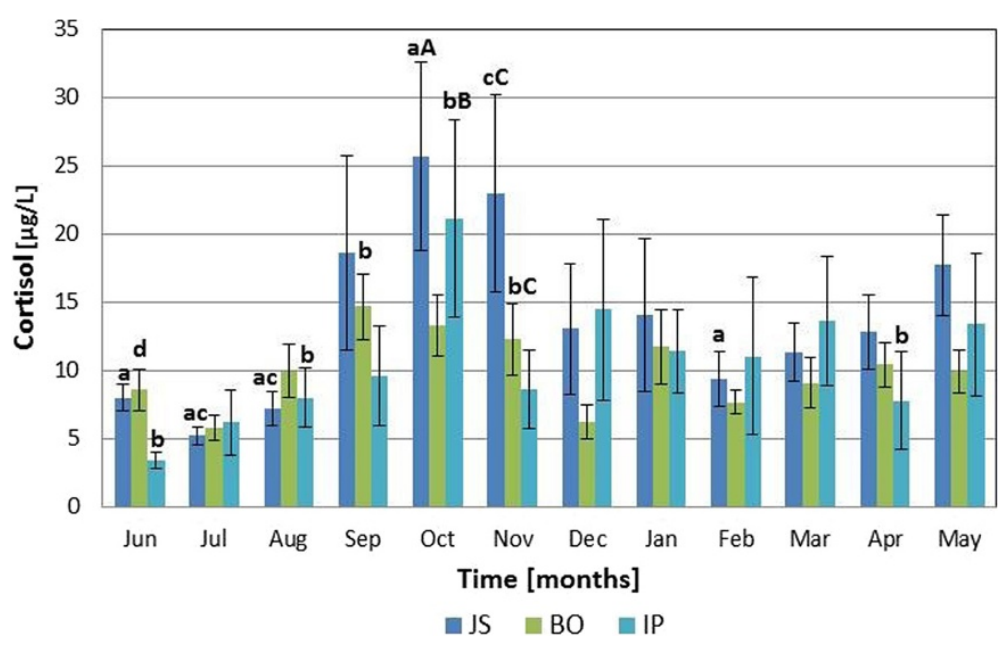

Figure 1 Monthly cortisol fluctuations in Jezersko-Solchava (JS), Bovec (BO) and Istrian (IP) ewes (mean \pm s.e.m.). Legend: $a-P<0.001$ for October versus June, July, August and February (in JS); $b-P<0.001$ for October versus June, August, November and April (in IP), $c-P<0.001$ for November versus August (in JS), $d-P<0.05$ for September versus June and December (in $B O$ ), $A-P<0.05$ for JS versus $B O$ (in October), $B-P<0.05$ for IP versus $B O$ (in October), $C-P<0.05$ for JS versus IP (in November).

stressor [7-11] were not reasons for the observed cortisol fluctuations, as the investigated ewes were familiar with humans, used to various procedures, not separated from each other and treated carefully during samplings to avoid any excitement or escaping. Another argument for our conclusion are cortisol concentrations, which were reported for sheep subjected to various forms of stress, exceeding the values obtained in our presented study (see Figure 1). Isolation stress in Comissana [9] and in Dorest-sired crossbred ewes [11] induced the rise of cortisol concentrations (over $90 \mu \mathrm{g} / \mathrm{L}$ and $120 \mu \mathrm{g} / \mathrm{L}$ respectively), while shearing and yarding of mature Merino ewes increased cortisol concentrations to the values over $60 \mu \mathrm{g} / \mathrm{L}$ [25]. Elevation of cortisol concentrations was also measured after the ACTH administration (over $46 \mu \mathrm{g} / \mathrm{L}$ in Suffolk $\times$ Hampshire ewes [10], over $80 \mu \mathrm{g} / \mathrm{L}$ in Dorest-sired crossbred ewes [11]). High levels of cortisol in autumn and winter have also been found in other sheep breeds $[3,6]$. A vital factor that stimulates the pituitary-adrenal axis and cortisol secretion in autumn and winter months might be increased production of $\mathrm{LH}$, promoting the onset of puberty [26] and seasonal reproductive activity in yearling ewes, which started between

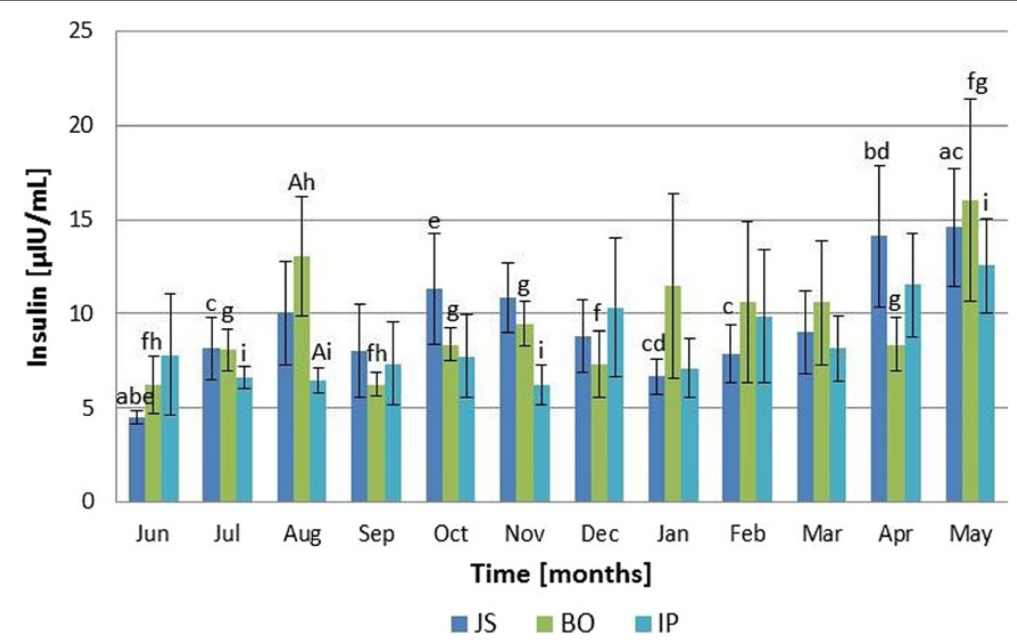

Figure 2 Monthly insulin fluctuations in Jezersko-Solchava (JS), Bovec (BO) and Istrian (IP) ewes (mean \pm s.e.m.). Legend: $a-P<0.01$ for May vs. June (in JS); $b-P<0.01$ for April vs. June (in JS); $c-P<0.05$ for May vs. July, January and February (in JS); $d-P<0.05$ for April vs. January (in JS); $e-P<0.05$ for October vs. January (in JS); $f-P<0.01$ for May vs. June, September and December (in BO); $g-P<0.05$ for May vs. April, July, October and November (in BO); $h-P<0.05$ for August vs. June and September (in BO); $i-P<0.05$ for May vs. July, August and November (in IP); $A-P<0.05$ in $B O$ versus IP. 


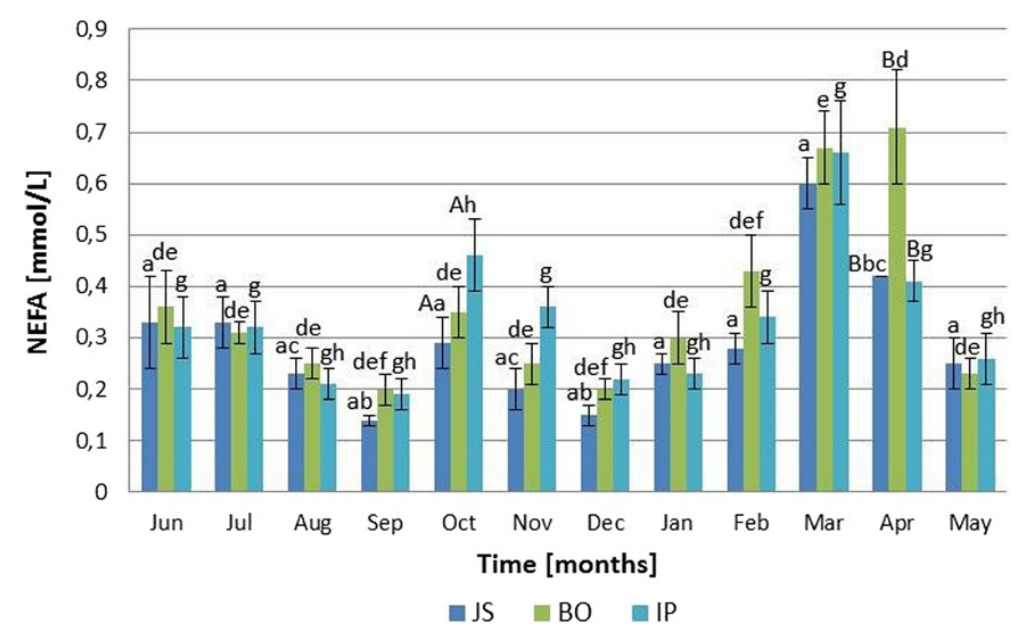

Figure 3 Monthly NEFA fluctuations in Jezersko-Solchava (JS), Bovec (BO) and Istrian (IP) ewes (mean \pm s.e.m.). $a-P<0.001$ for March vs. June - February and May (in JS); $b-P<0.001$ for April vs. September and December (in JS); $C-P<0.01$ for April vs. August and November (in JS); $d-P<0.001$ for April vs. June - February, May (in BO); e - $P<0.001$ for March vs. June - February, May (in BO); $f-P<0.001$ for February vs. September and December (in BO); $g-P<0.001$ for March vs. June - September, November - February, April and May (in IP); $h-P<0.001$ for October vs. August, September, December, January and May (in IP); $A-P<0.01$ for IP vs. JS in October, $B-P<0.01$ for BO vs. JS and IP in April.

September and November, as is seen from the estimation of ovarian activity (Table 2). Therefore, a factor that probably contributed to observed cortisol elevations in autumn months was the onset of puberty in the ewes of all three examined breeds. Another explanation for cortisol levels peaking in autumn and not in winter might be associated with decreased environmental temperatures in autumn [18], presenting a strong stress factor for young ewes [27], which have not yet been protected with dense and long wool at that period [28]. An increase of blood cortisol was reported in sheep during long-term cold exposure [29,30], followed by a metabolic acclimatization [30]. In the present

Table 3 Correlation coefficients $\left(r^{2}\right)$ between the body weights (BW), serum cortisol, insulin, and NEFA concentrations in Jezesko-Solchava (JS), Bovec (BO) and Istrian (IP) breeds of sheep

\begin{tabular}{lccccc}
\hline & & BW & cortisol & insulin & NEFA \\
\hline JS $(n=10)$ & BW & 1 & 0.260 & $0.632^{*}$ & 0.432 \\
& cortisol & 0.260 & 1 & 0.434 & -0.209 \\
& insulin & $0.632^{*}$ & 0.434 & 1 & 0.197 \\
& NEFA & 0.247 & 0.542 & -0.048 & 1 \\
BO $(n=10)$ & BW & 1 & -0.012 & 0.413 & 0.394 \\
& cortisol & -0.012 & 1 & 0.005 & -0.109 \\
& insulin & 0.413 & 0.005 & 1 & 0.080 \\
& NEFA & 0.394 & -0.109 & 0.080 & 1 \\
$\mathbb{I P ~}(n=10)$ & BW & 1 & 0.490 & $0.742^{* *}$ & -0.006 \\
& cortisol & 0.490 & 1 & 0.254 & 0.308 \\
& insulin & $0.742^{* *}$ & 0.254 & 1 & -0.351 \\
& NEFA & -0.006 & 0.308 & -0.351 & 1 \\
\hline
\end{tabular}

Legend: *significant correlation $(P<0.05)$, ${ }^{*}$ significant correlation $(P<0.01)$. study, cortisol levels in September and October were almost the same as were found in the study of Graham et al. [30] who determined cortisol in sheep during cold exposure. On the other hand, low cortisol concentrations during the summer were probably associated with high environmental temperatures; this phenomenon has also been found in heifers [31]. Thus, results of this study suggest that increased cortisol secretion was associated with low temperatures and reproduction activity or combination of both. However, in September and October reproduction activity was found only in some particular animals (Table 2), therefore, we believe that decrease of environmental temperature at that time leads to stimulation of cortisol secretion.

Insulin levels in all three breeds at all sampling times were in line with insulin values reported for adult Romane breed ewes [32] reared outdoors $(10-30 \mu \mathrm{IU} /$ $\mathrm{mL}$ ) and for individually housed Merino lambs [13] of both genders aged 60 and 360 days $(5 \mu \mathrm{IU} / \mathrm{mL}$ and $5-$ $10 \mu \mathrm{IU} / \mathrm{mL}$, respectively) but higher than in individually housed Soay rams [14] during short-day or long day photoperiod $(0.17 \pm 0.05 \mu \mathrm{IU} / \mathrm{mL}$ and $0.16 \pm 0.01 \mu \mathrm{IU} / \mathrm{mL})$. Several other studies report insulin concentrations in various breeds of sheep, like in pregnant blue-faced Leichester cross Swaledal ewes [33], western White-Faced ewes [34] and Rambouillet ewe lambs [35], kept indoors in individual pens. The sheep in these studies [33-35] were kept under various experimental conditions, various procedures were used for insulin measurement and the results were presented in other units, which all make these results difficult to compare with results of our study.

In Jezersko-Solchava breed mean annual insulin and cortisol values were both found to be high, followed by the values determined in Bovec and Istrian breeds, however 
the differences were insignificant. In evaluating the results of our study, we believe that some metabolic parameters (e. g. blood glucose level) are kept by the maintenance of relations between blood insulin and cortisol concentrations due to their physiological antagonistic effect. Similarly to Gatford et al. [13], a gradual increase of insulin levels was found in the examined ewes, which was in parallel to their growth. Additionally, significant positive correlation between body weight and insulin level was found in Jezersko-Solchava and Istrian breeds (Table 3). It is reported that sensitivity to insulin in humans decreases during and after puberty [36]. Thus, as body weight increases, higher insulin secretion is required to reach the same effect as was reached with lower levels in younger animals. The results of the presented study indicate a similar effect in investigated sheep breeds.

In contrast to insulin, NEFA concentrations were found to significantly fluctuate over the year (Figure 3). NEFA values in all three examined breeds were found to be low during most of the year and were comparable to other sheep breeds with positive energy balance $[14,32]$.

NEFA concentrations in adult Romane breed ewes reared outdoors ranged from approximately $0,9 \mathrm{mmol} / \mathrm{L}$ before to $0.2 \mathrm{mmol} / \mathrm{L}$ after weaning and increased again to the values of about $0.6 \mathrm{mmol} / \mathrm{L}$ after mating, reflecting various levels of body reserve mobilisation harmonized with energy needs in various states of reproductive activity [32]. In adult Soay rams an increase of NEFA levels was observed [14] after the 60-day period of restricted feeding, which has followed a period with freely available food $(0.285 \pm 0.047$ vs. $0.461 \pm$ $0.056 \mathrm{mmol} / \mathrm{L}$ in short-day photoperiod and $0.106 \pm 0.012$ vs. $0.310 \pm 0.031 \mathrm{mmol} / \mathrm{L}$ long-day photoperiod). In the present study NEFA levels peaked in March (JezerskoSolchava and Istrian breeds) or April (Bovec breed). Another NEFA peak was detected in October in all examined breeds, significant only in Istrian breed. Blood NEFA concentrations were found to be elevated during times of insufficient feed supply, since low blood glucose levels induce the mobilization of fatty acids from adipose tissue in the form of NEFA [15 - 17]. Additionally, a low insulin level is also significant factor that stimulates the hormone-sensitive lipase activity, resulting in NEFA mobilization $[37,38]$. Therefore, elevated NEFA values measured in the investigated ewes can be considered as markers for insufficient feed supply in October, and more prominent in March and April. Slow growth in Bovec and Istrian ewes and even loss of body weight in Jezersko-Solchava ewes were found during the same period (Table 1), which also indicates the inadequate supply with nutrients. Losses of dry matter and nutrients in large round bales, stored outside, as also at our farm, ranges from 3 to $40 \%$, with increase of fibre concentrations due to the loss of non-fibre constituents. Because the loss is primarily highly digestible nutrients, the digestibility of forage dry matter decreases during storage [39], which can also be the reason for decreased quality of the food, available to investigated ewes in spring months.

Similarly, increased NEFA levels in October could be a result of low herbage quality in autumn and, therefore, qualitatively insufficient feed supply. The studies of feed in dry Karst pastures have shown the reduction of herbage quality in summer and autumn months, which is caused by drought, which is a recurring problem in the dry Mediterranean karst grasslands [40,41]. This presumption was confirmed by similar NEFA fluctuations in all three tested breeds, which were bred under the same conditions.

Nevertheless, the results of the present study do not differentiate between endogenous (e.g. growth, onset of puberty, circannual hormone patterns, etc.) and exogenous (e.g. feed supply, environmental conditions, etc.) factors that influence monthly fluctuations of hormone secretion and energy metabolism. We believe that yearling ewes of various breeds bred across the Northern Mediterranean are subjected to similar environmental factors during their growth, since they are born in the late winter months. Considering this, cortisol, insulin and NEFA annual fluctuations in growing ewes could be somewhat universal and present additional data in understanding the regulation of energy metabolism and the adaptability to environmental conditions in the studied category of sheep.

\section{Conclusions}

We conclude that in the Jezersko-Solchava, Bovec and Istrian breeds of sheep, the annual fluctuations of cortisol, insulin and NEFA were present, following the similar patterns in all examined breeds. Between-breed differences in monthly values of examined parameters were insignificant. Elevated cortisol levels were measured in autumn and could be associated with the onset of puberty and seasonal reproductive activity and/or low environmental temperature as a stress factor. Insulin levels in growing ewes increased with body weight and were probably not significantly influenced by environmental factors. Elevated NEFA levels were found in autumn and spring, corresponding to an insufficient quality of feed supply that was available to sheep. Nevertheless, the evaluation of annual cortisol, insulin and NEFA fluctuations presents further information in the understanding of energy metabolism regulation and adaptive mechanisms to environmental conditions in growing ewes.

\section{Abbreviations}

NEFA: Non-esterified fatty acids; EIA: Enzyme immunoassay; CV: Coefficient of variation; RM ANOVA: Repeated measures analysis of variance; BW: Body weight; LH: Luteinizing hormone; ACTH: Adrenocorticotropic hormone.

\section{Competing interests}

The authors declare that they have no competing interests. 


\section{Authors' contributions}

TS has actively participated in both data analyses and preparation of the manuscript; ZJ has organized the samplings, performed statistical analyses and collaborated in preparation of the manuscript; NCK was the leader of the project and has performed the sample analyses as well as collaborated in preparation of the manuscript. All authors read and approved the final manuscript.

\section{Acknowledgements}

The study was financially supported by the Slovenian Research Agency grant P4-0053. The authors are grateful for the technical assistance given by $\mathrm{Mr}$ Bostjan Drolc. The authors are thankful also to Mr Terry T. Jackson for review of English.

\section{Author details}

${ }^{1}$ Institute of Physiology, Pharmacology and Toxicology, University of Ljubljana, Veterinary faculty, Gerbiceva 60, Ljubljana, Slovenia. ${ }^{2}$ Gubceva 7, llirska Bistrica, Slovenia.

Received: 4 June 2014 Accepted: 5 October 2014

Published: 18 October 2014

\section{References}

1. Greco DS, Stabenfeldt GH: Endocrinology. In Textbook of Veterinary Physiology. 4th edition. Edited by Cunningham JG, Klein BG. Philadelphia: Saunders; 2007:409-464.

2. Ferguson DC, Dirikolu L, Hoenig M: Glucocorticoids, mineralocorticoids and adrenolytic drugs. In Veterinary Pharmacology and Therapeutics. 9th edition. Edited by Riviere JE, Papich MG. Ames: Wiley-Blackwell; 2009:771-802.

3. Nazki AR, Rattan PJS: Some hormonal and biochemical characteristics of blood in sheep as related to different seasonal environments. Ind Vet J 1991, 68:28-32.

4. Thun R, Schwartz-Porsche D: Nebennierenrinde. In Veterinärmedizinische Endokrinologie. 3rd edition. Edited by Döcke F. Jena: Gustav Fischer; 1994:357-398.

5. Brinklow BR, Forbes JM: Effect of pinealectomy on the plasma concentrations of prolactin, cortisol and testosterone in sheep in short and skeleton long photoperiods. J Endocrinol 1984, 100:287-294.

6. Gomez Brunet A, Lopez Sebastian A: Effect of season on plasma concentrations of prolactin and cortisol in pregnant, non-pregnant and lactating ewes. Anim Reprod Sci 1991, 26:251-268.

7. Hall SJG, Forsling ML, Broom DM: Stress response of sheep to routine procedures: changes in plasma concentrations of vasopressin, oxytocin and cortisol. Vet Rec 1998, 142:91-93.

8. Moolchandani A, Sareen M, Vaishnav J: Influence of restraint and isolation stress on plasma cortisol in male Karakul sheep. Vet Arh 2008, 78:357-362.

9. Caroprese M, Albenzio M, Marzano A, Schena L, Annicchiarico G, Sevi A: Relationship between cortisol response to stress and behavior, immune profile, and production performance of dairy ewes. J Dairy Sci 2010, 93:2395-2403.

10. Yates DT, Ross TT, Hallford DM, Yates $\sqcup$, Wesley RL: Technical note: Comparison of salivary and serum cortisol concentrations after adrenocorticotropic hormone challenge in ewes. J Anim Sci 2010, 88:599-603.

11. Minton JE, Apple JK, Parsons KM, Blecha F: Stress-associated concentrations of plasma cortisol cannot account for reduced lymphocyte function and changes in serum enzymes in lambs exposed to restraint and isolation stress. J Anim Sci 1995, 73:812-817.

12. Kiani A: Temporal changes in plasma concentration of leptin, IGF-1, insulin and metabolites under extended fasting and re-feeding conditions in growing lambs. Endocrinol Metab 2013, 11:34-40.

13. Gatford KL, De Blasio MJ, Thavaneswaran P, Robinson JS, McMillen IC, Owens JA: Postnatal ontogeny of glucose homeostasis and insulin action in sheep. Am J Physiol Endocrinol Metab 2004, 286:1050-1059.

14. Marie M, Findlay PA, Thomas L, Adam CL: Daily patterns of plasma leptin in sheep: effects of photoperiod and food intake. J Endocrinol 2001, 170:277-286.

15. Grummer RR: Etiology of lipid-related metabolic disorders in periparturient dairy cows. J Dairy Sci 1993, 76:3882-3896.

16. Drackley JK, Andersen JB: Splanchnic metabolism. In Ruminant physiology. Digestion, metabolism and impact of nutrition on gene expression, immunology and stress. 1st edition. Edited by Seyrsen K, Hvelplund T, Nielsen MO. Wageningen: Kluwer; 2006:199-224.
17. Dunchea FR, Bell AW, Trigg TE: Relations between plasma non-esterified fatty acid metabolism and body fat mobilization in primiparous lactating goats. Br J Nutr 1989, 62:51-61

18. Slovenian environment agency: ARHIV - opazovani in merjeni meteorološki podatki po Sloveniji; http://meteo.arso.gov.si/met/sl/archive/.

19. Nemec $M$, Klinkon $M$ : Determination of free fatty acids and $\beta$-hydroxybutirate in blood serum with automatic analyser. Res Rep - Univ Ljubl Vet Fac 1999, 36:205-210.

20. Milton JE, Coppinger TR, Spaeth CW: Poor reproductive response of anestrous Suffolk ewes to ram exposure is not due to failure to secrete luteinizing hormone acutely. J Anim Sci 1990, 69:3314-3320.

21. Rhodes L, Nathanielsz PW: Myometrical activity and plasma progesterone and oxytocin concentrations in cycling and early-pregnant ewes. Biol Reprod 1990, 41:834-841.

22. Dickie MB, Holzmann A: Untersuchungen zum einsatz von Progesteronschnelltests (Serozyme - Progesteron, Ovucheck) zur Graviditätsdiagnose beim österreichischen Bergschaff. J Vet Med A 1992, 39:525-530

23. Campos Ferra J, Cieslak S, Sartori Filho R, McManus C, Frederico Martins C, Robson Bezerra Sereno J: Weight and age at puberty and their correlations with morphometric measurements in crossbred breed Suffolk ewe lambs. R Bras Zootec 2010, 39:134-141.

24. Turner Al, Canny BJ, Hobbs RJ, Bond JD, Clarke1 IJ, Tilbrook AJ: Influence of sex and gonadal status of sheep on cortisol secretion in response to $\mathrm{ACTH}$ and on cortisol and LH secretion in response to stress: importance of different stressors. J Endocrinol 2002, 173:113-122.

25. Fulkerson WJ, Jamieson PA: Pattern of cortisol release in sheep following administration of synthetic ACTH or imposition of various stressor agents. Aust J Biol Sci 1982, 35:215-222.

26. Buchingham JC, Dohler KD, Wilson CA: Activity of the pituitary-adrenocortical system and thyroid gland during the oestrus cycle of the rat. $J$ Endocrinol 1978, 78:359-366.

27. Alexander $G$, Bell $A V$ : The role of the adrenal gland in the metabolic response of young lambs to cold. J Dev Physiol 1982, 4:53-73.

28. Pearson AJ, Parry AL, Askby MG, Chory VJ, Wildermoth JE, Craven AJ: Inhibitory effect on increased photoperiod on wool follicle growth. J Endocrinol 1996, 148:157-166.

29. Maurya VP, Sejian V, Naqvi SMK: Effect of cold stress on growth, physiological responses, blood metabolites and hormonal profile of native Malpura lambs under hot semi-arid tropics of India. Ind J Anim Sci 2013, 83:370-373.

30. Graham AD, Christopherson RJ, Thompson JR: Endocrine and metabolic changes in sheep associated with acclimation to constant intermittent cold exposure. Can J Anim Sci 1981, 61:81-90.

31. Abilay TA, Johnson HD, Madan ML: Influence of environmental heat on peripheral plasma progesterone and cortisol during the bovine oestrus cycle. J Dairy Sci 1975, 58:1836-1840.

32. González-García E, Gozzo De Figuereido V, Foulquie E, Jousserand D, Autran P, Camous S, Tesniere A, Bocquier F, Jouvena M: Circannual body reserve dynamics and metabolic profile changes in Romane ewes grazing on rangelands. Dom Anim Endocrinol 2014, 46:37-48.

33. Gardner DS, Tingey K, Van Bon BWM, Ozanne SE, Wilson V, Dandrea J, Keisler DH, Stephenson T, Symonds ME: Programming of glucose insulin metabolism in adult sheep after maternal undernutrition. Am J Physiol Regul Integr Comp Physiol 2005, 289:947-954.

34. Kiyma Z, Alexander BM, Van Kirk EA, Murdoch WJ, Hallford DM, Moss GE: Effects of feed restriction on reproductive and metabolic hormones in ewes. J Anim Sci 2004, 82:2548-2557.

35. Vonnahme KA, Luther JS, Reynolds LP, Carlson DB, Redmer DA, Caton JS: Impacts of maternal selenium and nutritional level on growth, adiposity, and glucose tolerance in female offspring in sheep. Dom Anim Endocrinol 2010, 39:240-248.

36. Goran Ml, Gower B: Longitudinal studies on pubertal insulin resistance. Diabetes 2001, 50:2444-2450.

37. Herdt TH: In Textbook of Veterinary Physiology. 4th edition. Edited by Cunningham JG, Klein BG. Philadelphia: Saunders; 2007:299-407.

38. Regnault TRH, Oddy HV, Nancarrow C, Sriskandarajah N, Scaramuzzi RJ: Glucose-stimulated insulin response in pregnant sheep following acute suppression of plasma non-esterified fatty acid concentrations. Reprod Biol Endocrinol 2004, http://www.rbej.com/content/pdf/14777827-2-64.pdf. 
39. Rotz CA, Muck RE: Changes in forage quality during harvest and storage. In Forage Quality, Evaluation, and Utilization. Edited by Fahey GC Jr. Madison, WI: Am. Soc. Agron; 1994:828-868.

40. Vidrih T, Pogačnik M, Juntes P, Kompan D, Krek V, Kotnik T: Controlled grazing for small ruminants as a tool for sustainable management in karst grassland. In Systemes sylvopastoraux pour un environnement, une agriculture et une economie durables. Zaragoza: CIHEAM; 1995:139-142.

41. Kotnik T, Vidrih T: Seasonal changes in sward composition of karst pasture. Sci Pract Agric Food Technol 1994, 24:156-161.

doi:10.1186/2046-0481-67-22

Cite this article as: Snoj et al: Fluctuations of serum cortisol, insulin and non-esterified fatty acid concentrations in growing ewes over the year. Irish Veterinary Journal 2014 67:22.

\section{Submit your next manuscript to BioMed Central and take full advantage of:}

- Convenient online submission

- Thorough peer review

- No space constraints or color figure charges

- Immediate publication on acceptance

- Inclusion in PubMed, CAS, Scopus and Google Scholar

- Research which is freely available for redistribution 